\title{
In Vitro Molecular Reconstitution of the Respiratory Burst in B Lymphoblasts from p47-phox-deficient Chronic Granulomatous Disease
}

\author{
Bryan D. Volpp and Yun Lin \\ Department of Medicine, College of Medicine, The University of Iowa and \\ the Veterans Administration Medical Center, Iowa City, Iowa 52242
}

\begin{abstract}
Epstein-Barr virus-transformed lymphocytes generate superoxide in response to various agonists in an enzymatic reaction similar to that which occurs in stimulated phagocytes. We generated transformed B lymphoblast cell lines from controls, from four patients with p47-phox-deficient chronic granulomatous disease, and from three parents. The cells from controls and from the parents generated 7.0-35 nmol of $\mathrm{O}_{2}^{-} / 10^{7}$ cells per $30 \mathrm{~min}$ in response to phorbol myristate acetate. None of the patient cell lines generated any detectable superoxide. Both p47-phox and p67-phox were detected by immunoblot in the cytosol of control and parent cell lines and, as in neutrophils, these proteins had affinity for GTP-agarose. The patients' cell lines contained no detectable p47-phox by immunoblot. mRNA for both cytosolic proteins was detected in all cell lines. We generated cDNA and obtained multiple clones from two patients by polymerase chain reaction. One patient was a compound heterozygote with each allele resulting in an early stop codon. Clones derived from the other patient demonstrated only a GT deletion at base 75. The cDNA for p47-phox was inserted into an EBV-expression vector and stably transfected cell lines were obtained using hygromycin B selection. Transfected cell lines from a p47-phox-deficient patient generated normal levels of superoxide and had readily detectable cytosolic p47phox. Thus, B lymphoblasts provide an excellent model system for studies of the NADPH oxidase, for expression of functional recombinant forms of oxidase components, and for initial experimental approaches to genetic reconstitution in CGD. (J. Clin. Invest. 1993.91:201-207.) Key words: superoxide • NADPH oxidase $\bullet$ neutrophil $\bullet$ chronic granulomatous disease $\bullet$ genetics
\end{abstract}

\section{Introduction}

The phagocyte NADPH oxidase catalyzes the transfer of electrons from NADPH to molecular oxygen to generate superoxide anion, a reaction that is vital for the host's defense against many microorganisms (1-3). The presence of NADPH oxidase activity similar to the phagocyte enzyme has been recently described in other cell types (4-7). In particular, B lymphocytes transformed by EBV produce superoxide anion in response to various agonists $(5,8-11)$. The NADPH oxidase is a multicomponent enzyme that is defective in patients with chronic granulomatous disease of childhood (CGD) ${ }^{1}(3,12)$.

Address reprint requests to Dr. Bryan D. Volpp, Department of Medicine, SW-54 GH, 200 Hawkins Drive, Iowa City, IA 52242.

Received for publication 24 April 1992 and in revised form 4 August 1992.

The Journal of Clinical Investigation, Inc.

Volume 91, January 1993, 201-207
The enzyme has at least four components: two subunits of the membrane bound cytochrome $b$, gp91-phox and p22-phox and two cytosolic components, p47-phox and p67-phox, which translocate to the membrane during activation of the neutrophil (13). Genetic absence of any one of these four proteins results in an inability to generate superoxide anion and the CGD clinical phenotype of recurrent severe infections with catalase positive organisms $(14,15)$.

The four known components of the oxidase have been cloned and sequenced and the genetic defects resulting in CGD have been described for some patients who lack these proteins. The absence of the large subunit of the $b$ cytochrome, gp91phox, may be the result of chromosomal deletions (16). In addition, point mutations in the coding sequence may result in a nonfunctional subunit. Some of these point mutations may provide insight into the function of specific protein domains in the generation of superoxide $(17,18)$. Single base deletions or point mutations resulting in early stop codons may result in the absence of the small subunit of the $b$ cytochrome p22-phox as well (19). A recent report describes a dinucleotide GT deletion at a tandem repeat in the coding region of $\mathrm{p} 47-$ phox as the cause of a deficiency of this protein in some patients (20); however, other defects have not yet been reported. The genetic basis of p67-phox deficiency remains to be elucidated.

We have used B lymphocyte cell lines derived from normal individuals and from patients with CGD as a model for the neutrophil NADPH oxidase. B cells transformed with EBV generate superoxide in response to a number of stimuli, including phorbol myristate acetate (PMA), calcium ionophores, and surface immunoglobulin cross-linking agents $(5,10,11)$. The rate of superoxide generation is less than that seen in PMNs, but the enzymatic mechanism appears to be the same. As in PMNs, the enzyme in B cells is not inhibited by cyanide and preferentially uses NADPH as a substrate (5). In addition, the cytochrome $b_{558}$ of the PMN NADPH oxidase has been found in small quantities in the plasma membrane of transformed B cells $(6,9)$, and the cytosolic components of the oxidase are present as well (21). We sought to determine if the cytosolic components in these EBV-transformed B cells were identical to those of the phagocyte NADPH oxidase and then to use these B lymphoblasts to determine the molecular basis of p47-phox deficiency and as a model system for expression of p47-phox cDNA.

\section{Methods}

Materials. Avian myeloblastosis virus reverse transcriptase, hygromycin B, and ( $N$-[1-(2,3-dioleoyloxy)propyl]- $N, N, N$-trimethyl ammonium methyl sulfate transfection reagent were obtained from Boeh-

1. Abbreviations used in this paper: CGD, chronic granulomatous disease; PCR, polymerase chain reaction. 
ringer Mannheim Biochemicals (Indianapolis, IN); cyclosporin A was obtained from Sandoz Pharmaceuticals Corporation (East Hanover, $\mathrm{NJ}$ ); ferricytochrome $c$, SOD, and GTP-agarose were obtained from Pharmacia LKB Biotechnology, Inc. (Piscataway, NJ); [ $\left.{ }^{32} \mathrm{P}\right] \mathrm{dCTP}$ and $\left[{ }^{35} \mathrm{~S}\right] \mathrm{dATP}$ were obtained from New England Nuclear (Boston, MA); RNasin was obtained from Promega Corp. (Madison, WI); S\&S Nytran was obtained from Midwest Scientific (Valley Park, MO); Taq DNA polymerase was obtained from Perkin-Elmer Cetus Instruments (Norwalk, CT); Bluescript plasmid was obtained from Stratagene, Inc. (La Jolla, CA); Sequenase was obtained from U. S. Biochemical Corp. (Cleveland, $\mathrm{OH}$ ); and PMA was obtained from Sigma Chemical Co. (St. Louis, MO).

$E B V$-transformed cell lines. Mononuclear cells were isolated from controls, parents, and patients by centrifugation of whole blood diluted 1:1 with HBSS over an equal volume of Hypaque-Ficoll at $26^{\circ} \mathrm{C}$ at 500 $g$ for $30 \mathrm{~min}$. The mononuclear cells were aspirated and washed in HBSS and then once in RPMI 1640. The cells were resuspended in RPMI 1640 supplemented with $15 \%$ fetal bovine serum and $1 \mu \mathrm{g} / \mathrm{ml}$ cyclosporin A at a density of $1 \times 10^{6}$ cells $/ \mathrm{ml}$. High titer EBV derived from B95-8 cells was added to the mononuclear cells in tissue culture medium as previously described (22). Colonies of transformed cells appeared within $3 \mathrm{wk}$. Patient S.R. has been previously reported (23) and patient 1 in reference 14 . Patients K.S., K.K., and C.B. were found to have a complete absence of reduction of nitroblue tetrazolium by nitroblue tetrazolium slide test (24) and an absence of $\mathrm{p} 47$-phox from the cytosol of PMNs by immunoblot.

Superoxide generation. Superoxide was measured in a discontinuous assay as the SOD-inhibitable reduction of cytochrome $c$. Actively growing cells were counted and washed once in HBSS and 4-8 $\times 10^{6}$ cells were resuspended in HBSS. PMA was added to both the reference and the sample to a final concentration of $500 \mathrm{ng} / \mathrm{ml}$ and SOD was added to the reference tube only. The cells were incubated for $5 \mathrm{~min}$ at $37^{\circ} \mathrm{C}$ before adding $5 \mu \mathrm{l}$ of $10 \mathrm{mM}$ cytochrome $c$. The cells were agitated during a $30-\mathrm{min}$ incubation at $37^{\circ} \mathrm{C}$ and then removed by microcentrifugation. The cytochrome $c$ reduction was measured using a dual-beam spectrophotometer as previously described $(25,26)$.

Immunoblots. The cytosolic components of the oxidase p47-phox and p67-phox were detected using a polyclonal antiserum previously described (27). B cells were washed, resuspended in phosphate buffered saline, and treated with $2 \mathrm{mM}$ diisopropylfluorophosphate before being disrupted by a microprobe sonicator (Ultrasonics, Inc., Plainview, NY). A $12,000 \mathrm{~g}$ supernatant was subjected to ultracentrifugation at 72,000 $\mathrm{g}$ for $6 \mathrm{~min}$. The supernatant was loaded on 9\% SDS polyacrylamide gels as previously described. The proteins were electrophoretically transferred to nitrocellulose paper, blocked with $5 \%$ nonfat dry milk in PBS, and probed with either the whole B-1 antiserum (27) or with B-1 antiserum that had been immunoaffinity purified to baculovirus expressed p47-phox and p67-phox by elution from nitrocellulose with $100 \mathrm{mM}$ glycine $\mathrm{pH} 2.5$ as previously described (28). Specific binding of antibody was detected with ${ }^{125}$ I-labeled Staphylococcal protein A or using a chemiluminescent method with horseradish peroxidase-conjugated goat anti-rabbit antibody according to the manufacturer's instructions (Amersham Corp., Arlington Heights, IL).

GTP-agarose affinity chromatography. Binding of protein to a GTP-agarose column was performed as previously described except that B cell cytosol was applied to the column (27).

RNA isolation and Northern analysis. Total cellular RNA was isolated from the transformed B cells by using RNAzol (Tel-test, Inc., Friendswood, TX). Samples of this RNA were separated in a $1 \%$ agarose/formaldehyde gel [ $6 \%$ formaldehyde in 3-( $N$-morpholino)propanesulfonic acid (MOPS) and blotted to S\&S Nytran that was treated with prehybridization and hybridization solutions according to manufacturer's instructions. Probes were radiolabeled with [ $\left.{ }^{32} \mathrm{P}\right] \mathrm{dCTP}$ using the method of random priming as described by Feinberg and Vogelstein (29). Final washes after hybridization were done under highly stringent conditions ( $1 \times \mathrm{SSC}, 0.1 \% \mathrm{SDS}, 60^{\circ} \mathrm{C}$ for $1 \mathrm{~h}$ ). cDNA was generated from the total cellular RNA isolated using avian myeloblasto- sis virus reverse transcriptase in the presence of RNasin as previously described (30).

Polymerase chain reaction (PCR) cloning, and sequencing. PCR was performed in 50- $\mu \mathrm{l}$ aliquots under light parafin oil in a thermocycler (Perkin-Elmer Cetus) in a $1 \times$ buffer of $16.7 \mathrm{mM}$ ammonium sulfate, $67 \mathrm{mM}$ Tris- $\mathrm{HCl}$ pH 8.0, 1.5-2.0 $\mathrm{mM} \mathrm{MgCl}_{2}, 10 \%$ DMSO, 200 $\mu \mathrm{M}$ each dNTP, $1 \mu \mathrm{M}$ each primer, $10 \mathrm{mM}$ 2-mercaptoethanol with $1.25 \mathrm{U}$ of Taq DNA polymerase per reaction with cycle times of $1 \mathrm{~min}$ at $95^{\circ} \mathrm{C}, 0.5 \mathrm{~min}$ at $54^{\circ} \mathrm{C}$, and $1 \mathrm{~min}$ at $72^{\circ} \mathrm{C}$. The primers used for amplification of $\mathrm{p} 47$-phox cDNA were $\mathrm{W} 0$ (bases -12 to +9 in the cDNA): 5'-TGGCCACCCAGTCATGGGGGAC-3' and C2 (bases 1,240-1,221 in the noncoding strand of the cDNA): 5'-TATAGAACACGTATGTACAGGC-3' $(28)$. The resulting $1.2-\mathrm{kb}^{\prime}$ products were treated with Klenow and blunt-end ligated into SmaI cut Bluescript SK. The resulting clones were sequenced using the M13 forward and reverse universal primers and using internal primers previously used to derive the entire p47-phox sequence (28). Sequencing was performed using the dideoxy sequencing method. Modified T7 DNA polymerase (Sequenase) was used with $\left[{ }^{35} \mathrm{~S}\right] \mathrm{dATP}(31)$. The gels were $1 \times \mathrm{TBE}, 8$ $\mathrm{M}$ urea, and $6 \%$ acrylamide with between 0 and $25 \%$ formamide added to resolve compressions.

Transfection of $B$ lymphoblast cell lines. The cDNA encoding $\mathrm{p} 47-$ phox was inserted into the HindIII/BamHI sites in p636, an EBV-expression vector kindly provided by Bill Sugden, University of Wiscon$\sin$. The vector contains the CMV promoter, the SV40 polyadenylation sequence, the EBV oriP gene, and a hygromycin B resistance gene for selection of transfected cells (32). Cells were transfected with either the vector alone, $\mathrm{p} 636$, or the vector containing the cDNA for $\mathrm{p} 47$-phox, p636-47 using DOTAP transfection reagent according to the manufacturer's instructions. Cells were placed in medium containing $200 \mu \mathrm{g}$ of hygromycin B $48 \mathrm{~h}$ after transfection.

\section{Results}

B lymphoblast cell lines. We generated B cell lines from five normal individuals, from both parents of a patient (W.S. and P.S.), from the mother of a patient (D.K.), and from four patients with p47-phox-deficient CGD (C.B., S.R., K.S., and K.K.). Table I shows the amount of superoxide generated in 30 min in response to $500 \mathrm{ng} / \mathrm{ml}$ of PMA. During the initial weeks in culture, all of the cell lines produced only barely detectable amounts of superoxide using either the static assay described above or a continuous assay. After 4 to $12 \mathrm{wk}$ in culture, superoxide production reached an easily detectable level (data not shown). The events responsible for this gradual rise in superoxide production are not known. As has been previously demonstrated (10), there was a dose response to PMA. The cell lines derived from the p47-phox-deficient patients generated no superoxide even after up to 16 mo in culture.

p47-phox and p67-phox in cytosol. Immunoblots of the cytosol derived from the B lymphoblast cell lines were probed with immunoaffinity-purified B-1 antiserum (Fig. 1). There were prominent bands at 67 and $47 \mathrm{kD}$ in the control cell lines (DC, WM, MS, CL, KA) but the 47-kD band was absent from the cytosol of the CGD cell lines (CB, SR, KS, and KK).

The cytosols from neutrophils, from one control cell line (CL), and from patient cell lines SR and KS (KS not shown) were subjected to GTP-agarose affinity chromatography. The eluates from one such representative experiment are shown in Fig. 2. p47-phox and p67-phox are the two major bands seen in the immunoblot of the GTP-agarose column eluates. The eluate fraction from the SR cell line contains no p47-phox and slightly less p67-phox than the control cells. This diminution in 
Table I. Superoxide Generation by EBV-transformed B Cell Lines from Controls, Parents of p47-phox-deficient Patients, and Patients with p47-phox Deficiency

\begin{tabular}{ccc}
\hline Cell line & Superoxide & $n$ \\
\hline & nmol of $O_{2}^{-} / 10^{7}$ cells per $30 \mathrm{~min}$ & \\
Controls & & \\
DC & $35.0 \pm 5.0^{*}$ & 2 \\
WM & $10.2 \pm 1.7$ & 3 \\
MS & $32.8 \pm 3.3$ & 2 \\
CL & $18.2 \pm 11.3$ & 18 \\
KA & $7.0 \pm 9.0$ & 8 \\
Parents & & \\
WS & $22.2 \pm 3.9$ & 4 \\
PS & $17.2 \pm 10.8$ & 6 \\
DK & $8.6 \pm 4.3$ & 7 \\
Patients & & \\
CB & 0 & 5 \\
SR & 0 & 6 \\
KS & 0 & 4 \\
KK & $0.1 \pm 0.1$ & 6 \\
\hline
\end{tabular}

* Mean \pm SE.

p67-phox is due to the elution of a portion of the p67-phox from this cell line from the column in the eluate fraction immediately preceding the fraction shown in this figure. This suggests that in the absence of p47-phox, the affinity of p67-phox for the GTP-agarose column is slightly reduced but that p67phox will bind to GTP-agarose independently of p47-phox. This was a consistent finding in four such experiments.

Analysis of $m R N A$. Fig. 3 shows the Northern blot of the total cellular RNA derived from the various cell lines. The blot was initially probed with ${ }^{32} \mathrm{P}$-labeled p47-phox cDNA (28) and a single band was detected at $1.4 \mathrm{~kb}$ from each cell line. The blot was subsequently probed with ${ }^{32} \mathrm{P}$-labeled p67-phox cDNA (33). A 2.2-kb band was detected in each lane. The Northern was striped and reprobed with an a ${ }^{32} \mathrm{P}$-labeled actin cDNA. Analysis of the Northern blot by densitometry demonstrated that the relative amounts of $\mathrm{p} 47$-phox signal were not consistently different between control and patient cell lines, suggesting that the amount of $\mathrm{p} 47$-phox mRNA is not significantly reduced in $\mathrm{p} 47$-phox-deficient patients. There was a marked variation in the amount of p67-phox detected by Northern blot among the various cell lines.

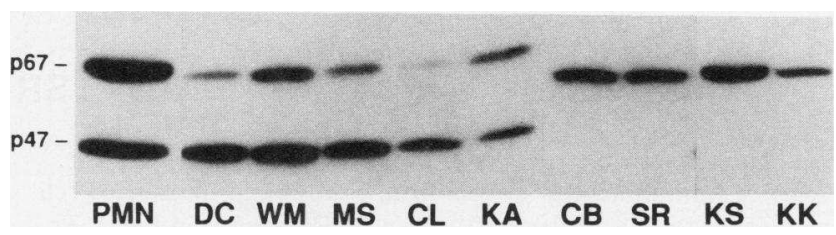

Figure 1. Immunoblot of cytosol from EBV-transformed cell lines. The cytosol from $5 \times 10^{6}$ cells was subjected to SDS-PAGE and electrophoretic transfer to nitrocellulose paper. Proteins recognized by the B-1 antiserum immunoaffinity purified to p47-phox and p67phox were detected with ${ }^{125}$ I-labeled Staphylococcal protein A. $P M N$, neutrophils; $D C, W M, M S, C L$, and $K A$, control cell lines; $C B, S R$, $K S$, and $K K, \mathrm{p} 47-$ phox-deficient patients.

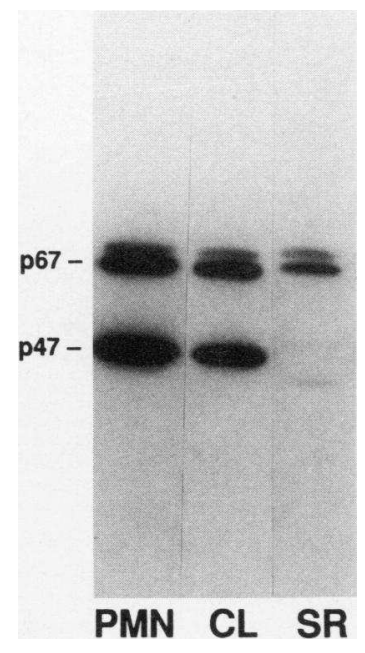

Figure 2. Immunoblot of cytosolic proteins eluted from GTP-agarose columns. Neutrophil cytosol $(P M N)$, the cytosol from the control $(C L)$, or p47-phox-deficient $(S R)$ cell lines was subjected to GTP-agarose affinity chromatography and the eluted fraction was analyzed by SDS-PAGE and transferred to nitrocellulose. Immunoreactive proteins were detected as in Fig. 1 using whole B-1 antiserum.

Total cellular RNA was treated with reverse transcriptase in the presence of oligo dT to generate cDNA. This cDNA was amplified by PCR using $\mathrm{p} 47$-phox-specific primers. The products were blunt-ended with Klenow and cloned for sequencing. We derived eight clones from the SR (CGD) cell line, five from the KS (CGD) cell line, and three from the CL (normal control) cell line. The SR clones were obtained from two separate RNA preparations and a total of three independent PCR reactions. The clones derived from the $\mathrm{SR}$ cell line were of two types. The sequences of these clones are shown in Figure 4, $A$ and $B$. Five type A clones contained a GT deletion at base 75 in the coding sequence for p47-phox. This introduces a frameshift and an early stop codon at base 165 . Type A clones had a normal sequence at base 502 , the site at which three type B clones contained a $\mathrm{G}$ deletion. Type $\mathrm{B}$ clones were normal at base 75 . This single base 502 deletion also introduces a frameshift and an early stop codon at base 605 . The clones derived from KS and CL cell lines were obtained from two separate RNA preparations. All five clones derived from $\mathrm{KS}$ showed a

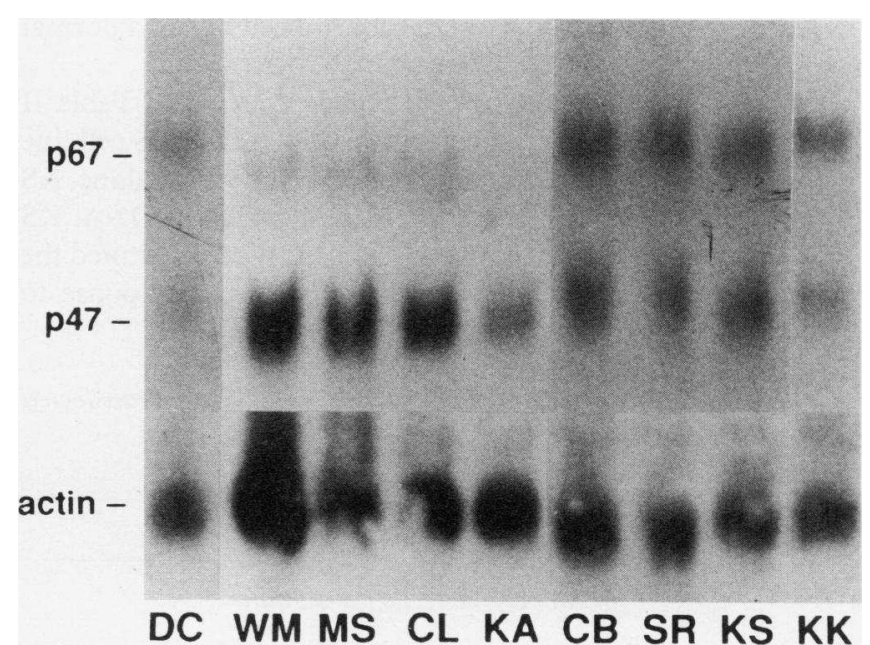

Figure 3. Northern blot of total cellular RNA derived from B lymphoblast cell lines. RNA from the same cell lines as in Fig. 1 were subjected to agarose gel electrophoresis and transfer to Nytran, hybridized to ${ }^{32} \mathrm{P}$-labeled cDNAs for p47-phox $(1.4 \mathrm{~kb})$ and $\mathrm{p} 67-$ phox $(2.2 \mathrm{~kb})$, and then subsequently to a labeled cDNA for actin. 

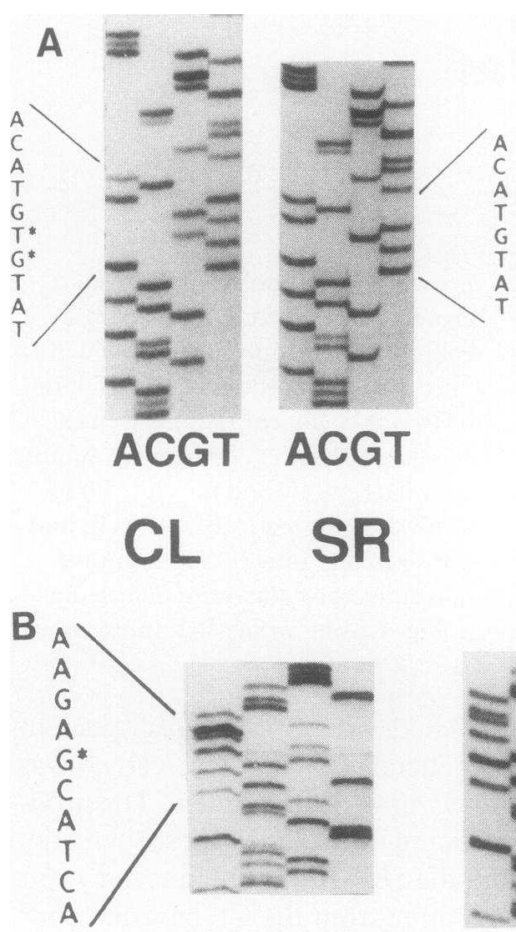

ACGT

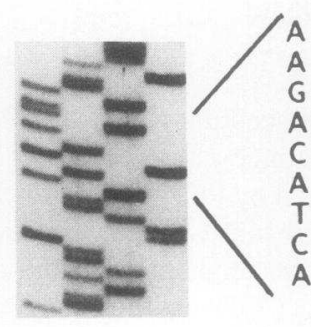

ACGT
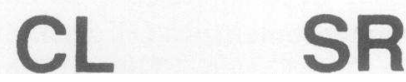

Figure 4. DNA sequence of subcloned p47-phox from a p47-phox-deficient patient. Nucleotide sequences of clones from control $(C L)$ and from deficient $(S R)$ cell lines. $(A)$ Sequence at base 72 in the cDNA shows a GT deletion. $(B)$ Sequence at base 502 in the cDNA shows a $G$ deletion. The cDNA sequence is available from EMBL/Genbank under the accession number M26193.

GT deletion at base 75 and normal sequence at base 502. All five of the clones derived from the control cell line had normal sequence at both sites.

Expression of p47-phox in a deficient cell line. Table II shows the amount of superoxide generated by the KS cell line before transfection; after transfection with the vector alone, KS + p636; and after transfection with the p47-phox cDNA, KS + p636-47. Transfection with $\mathrm{p} 47$-phox fully reconstituted the ability of whole cells to generate superoxide in response to

Table II. Superoxide Generation by the KS Cell Line Transfected with Vector Alone (p636) or Vector Containing the DNA for p47-phox (p636-47)

\begin{tabular}{lcc}
\hline \multicolumn{1}{c}{ Cell line } & Superoxide & $n$ \\
\hline \multicolumn{1}{c}{ nmol of $\mathrm{O}_{2}^{-} / 10^{7}$ cells per $30 \mathrm{~min}$} & \\
$\mathrm{KS}$ & $0.3 \pm 0.2^{*}$ & 5 \\
$\mathrm{KS}+\mathrm{p} 636$ & $0.4 \pm 0.2$ & 5 \\
$\mathrm{KS}+\mathrm{p} 636-47$ & $35 \pm 13$ & 5
\end{tabular}

* Mean \pm SE.
PMA whereas transfection of the vector alone had no effect. In addition, in combination with PMN membrane fractions, cytosol from the transfected cell line (KS + p636-47) supported superoxide production $\left(0.7 \pm 0.2 \mathrm{nmol}\right.$ of $\mathrm{O}_{2}^{-} / 10^{7}$ cell equivalents $/ \mathrm{min})$ whereas the cytosol from $\mathrm{KS}$ did not $(0.0 \pm 0.1$ $\mathrm{nmol})$. In this single experiment, this amount of superoxide production was equivalent to that produced by $1.2 \times 10^{6}$ cell equivalents of PMN cytosol. Fig. 5 shows an immunoblot of B cell cytosols probed with immunoaffinity-purified antibody to p47-phox. The cell line transfected with p636-47 expressed readily detectable $\mathrm{p} 47$-phox. Thus, expression of the $\mathrm{p} 47-$ phox protein was associated with functional reconstitution of the respiratory burst. This is the first reconstitution on the cellular level of the NADPH oxidase from a CGD patient.

\section{Discussion}

Studies of the structure and function of the NADPH oxidase of phagocytic cells have focused on the defective enzyme in patients with CGD of childhood. Four of the components of the enzyme have been revealed using PMNs or monocytes derived from these patients. However, progress has been hampered by a lack of cell lines and hence of appropriate models for study of the in situ interaction of various components of the enzyme. Since superoxide production in response to external stimuli has recently been reported in fibroblasts (4), mesangial cells (7), tonsilar B lymphocytes (9), and in lymphocytes immortalized by $\operatorname{EBV}(5,6,10)$ and since some of the membrane components of the phagocyte NADPH oxidase have been found to be present in these cells $(4,9)$, we postulated that the cytosolic components of the enzyme might be present as well. In addition, transformed B lymphoblasts demonstrate enhanced expression of surface adhesion molecules such as CD2, CD48, and LFA-3 as well as expression of the granulocyte-specific $f g r$ oncogene (34-36). Therefore, these B lymphoblasts have a

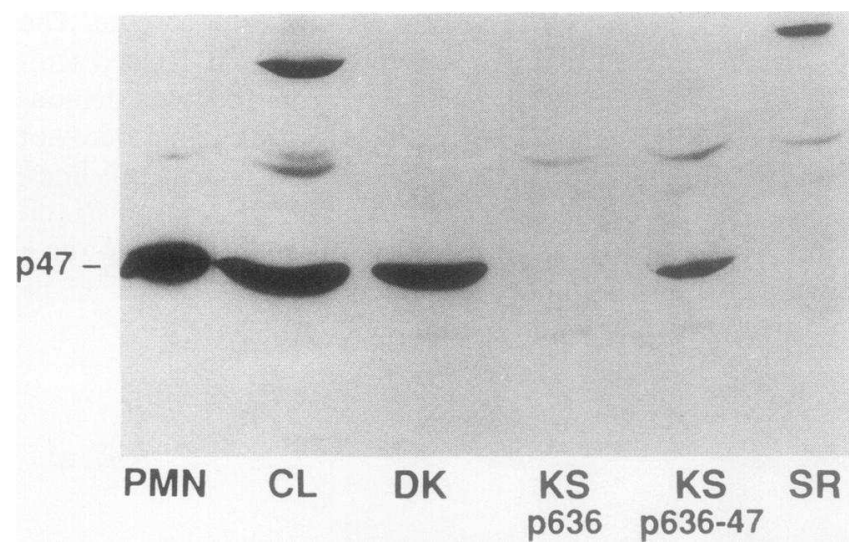

Figure 5. Immunoblot of cytosol from control and transfected cell lines. The cytosol from $10 \times 10^{6}$ cells was analyzed as in Fig. 1. Proteins recognized by the B-1 antiserum immunoaffinity purified to p47-phox were detected by chemiluminescence. $P M N$, neutrophils; $C L$, control cell line; $D K$, parent of a p47-phox-deficient patient; $K S$ p636, p47-phox-deficient patient cell line KS transfected with the vector alone; $K S p 636-47, \mathrm{KS}$ cell line transfected with the vector containing the cDNA for p47-phox; $S R$, nontransfected deficient cell line. 
number of characteristics in common with the differentiated granulocyte.

We generated 12 cell lines from patients and controls. The cell lines derived from the five controls and the parents of two patients with autosomal p47-phox-deficient CGD all generated superoxide in response to PMA. The cell lines derived from the patients with CGD lacked p47-phox and failed to generate any detectable superoxide. In addition, the p47-phox and p67-phox derived from these B cell lines bound to GTPagarose and are functional in a cell-free system (unpublished data and reference 21). Thus, the p47-phox and p67-phox derived from $B$ cell lines are functionally and immunochemically identical to the cytosolic components of the PMN NADPH oxidase.

The affinity of these two proteins for GTP-agarose has not been explained by their predicted amino acid sequence. p47phox contains only a partial sequence consistent with a nucleotide-binding domain (28) and p67-phox contains no elements characteristically found in nucleotide-binding proteins (33). In addition, recombinant $\mathrm{p} 67$-phox reportedly does not bind to GTP-agarose (37). It is therefore intriguing that even in the absence of p47-phox ( $\mathrm{p} 47$-phox-deficient B cell cytosol), p67phox does bind to GTP-agarose, albeit with less avidity (Fig. 2 ). One possible explanation is that an unidentified protein that is present in the cytosol of PMNs and transformed B lymphocytes mediates some portion of the GTP binding of p67phox. There are additional cytosolic components of the respiratory burst oxidase that are not yet well characterized (38). A possible candidate for such a role in mediating nucleotide binding would be the $32-\mathrm{kD}$ NADPH-binding component of the oxidase (39). This protein is cytosolic, translocates to the membrane of PMNs under the same conditions that result in p47-phox and p67-phox translocation (13), and binds to NADPH. Other proteins that could potentially mediate binding of a complex to GTP-agarose are the small molecular weight $G$ proteins, which appear to be important contributors to oxidase activation (40-44).

The $B$ cell lines provided adequate mRNA for both $p 47-$ phox and p67-phox for Northern analysis (Fig. 3) and for PCR amplification of cDNA. Analysis of this amplified cDNA revealed one of our patients (S.R.) to be a compound heterozygote, each allele resulting in a frame shift and an early stop codon. The other patient (K.S.) is likely homozygous for the GT deletion at base 75 since all clones derived from this patient have this sequence. Alternatively, K.S. could have a different abnormality that was either not represented in the clones we obtained or that resulted in a lack of mRNA production by one allele; this latter possibility is, however, not supported by the Northern blot, which shows a normal amount of p47-phox mRNA for K.S. compared with the other cell lines. The cDNA sequences for the other two patients (K.K. and C.B.) have not yet been evaluated.

The GT deletion at base 75 in the coding sequence for $\mathrm{p} 47$ phox in S.R. and K.S. has been reported in a few other p47phox-deficient patients as well (20). Single or dinucleotide deletions as a cause of a genetic disease commonly occur at sites of repetitive sequences (45). The GT deletion in p47phox occurs within the sequence TATGTGTA (bases 70-78). A similar GT deletion has been reported in the hypoxanthine ribosyltransferase gene within the sequence TGTGTG resulting in Lesch-Nyhan syndrome (46). Deletions of other dinucle- otides at repeats have also been reported (for review see reference 45 ). Such deletions are possibly secondary to mismatching of template and primer ( slippage) during DNA elongation. Other factors such as inverted repeats in flanking sequences or DNA polymerase arrest sites may contribute to the occurrence of such deletions as well $(45,47,48)$. And, in fact, in addition to the dinucleotide repeats in p47-phox at bases 70-78, there is also a set of inverted repeats. In the sequence flanking the deletion, bases 59-88 (CCAGCCAGCACTA TGTgtACA TGT T CCTGG), the underlined CCAGs are the inverted repeat of the underlined CTGG. Base pairing of the second CCAG with the CTGG could form the base of a hairpin loop in which 9 of 12 $\mathrm{bp}$ in this region hydrogen bond to form a stem that excludes the lower-case gt at the end of the loop (the lower-case gt represents the deletion). The formation of such hairpin loop structures is thought to contribute to deletions of segments greater than $1 \mathrm{bp}$ and can mediate deletions in vitro (47). Based on the presence of this deletion in our two patients and in the previously reported cases $(20)$, this is the most common abnormality resulting in $\mathrm{p} 47-$ phox deficiency. As demonstrated by patient S.R., however, there are other underlying genetic abnormalities that result in p47-phox deficiency, although no other abnormalities in the gene for p47-phox have been previously reported.

The single base deletion at base 502 in the coding sequence of p47-phox in S.R. is of interest considering the models for gene deletions that have been proposed $(45,47,48)$. The deleted $\mathrm{G}$ also lies in a region of repetitive sequence. The sequence from base 494 to 509 is CCGACTACgAGAAGAC, which demonstrates both GA repeats and a repeat of the sequence CGA. In addition, the sequence AGAAG is almost identical to the known DNA polymerase $\alpha$ arrest site AGGAG and to the deletion hotspot TGAAGA (45) (AGAAGA in p47phox). The trinucleotide sequences $A C G$ and GAG have been reported to be potential DNA polymerase $\alpha$ arrest sites also (49). Arrest sites for DNA polymerase $\alpha$ may contribute to the occurrence of base deletions by causing dissociation of the polymerase, thus allowing slippage of one strand on the other during DNA replication (45). As with the GT deletion at base 75 , the sequence surrounding the $G$ deletion at base 502 provides repetitive sequence elements as well as other characteristics that may contribute to the presence of a deletion at this site.

B lymphoblast cell lines from patients with some genetic diseases may serve as model systems for study. Hibbs et al. (34) restored LFA-1 expression and function in cell lines derived from CD18-deficient patients by transfection of the integrin $B$ subunit into these deficient EBV-transformed cells using a vector that replicates in EBV-transformed cells as an episome. We used a similar EBV-based vector to transfect the p47-phox-deficient cells from a CGD patient with the $\mathrm{p} 47-$ phox $\mathrm{cDNA}$. The transfected cell line produced approximately the same amount of superoxide in response to PMA as was produced by the control cell lines in spite of the fact that significantly less p47phox was present in the cytosol of the transfected cell line. Thus, expression of $\mathrm{p} 47$-phox in a deficient cell line completely reconstituted the respiratory burst in these cells.

CGD of childhood is fortunately a rare disease but patients with this disease have provided investigators with incisive experimental approaches in the evaluation of the NADPH oxidase. Research on the NADPH oxidase can be advanced in three major directions based on these results. First, as we and 
others (20, 21 ) have demonstrated, EBV-transformed lymphoblasts from patients and controls can serve as a source of functional protein and of mRNA. Thus, these cells allow for further evaluation of the genetic abnormalities underlying this disease. Second, since a complete analysis of structure-function relationships of the components of the NADPH oxidase and detailed studies of the activation of the enzyme require a wholecell system, cell lines from these patients will serve as a model system for study of the intermolecular interactions and function of the components of the NADPH oxidase. For example, transfection of mutated forms of p47-phox into deficient B cells should permit experimental definition of the domains of p47-phox responsible for such events as stimulus-dependent translocation to the plasma membrane. Third, these studies begin to establish a technical and conceptual framework for in vivo genetic reconstitution of the respiratory burst oxidase in patients with CGD of childhood. Although our studies to date have dealt with p47-phox-deficient CGD, similar approaches to molecular reconstitution of other forms of CGD may be possible in the future.

\section{Acknowledgments}

We are grateful to Dr. John Bennett for sharing his PCR protocols with us; Sherry Flanagan and Nadine Olin for secretarial assistance; Dr. William Nauseef and Sally McCormick for the transformation of the SR cell line; Kevin G. Leidal for technical assistance; Drs. James M. Stark, Jane Fossum, K. K. Caselton, Andreas van Egmond, Richard Hong, and the University of Wisconsin for the referral of patients K.S. and K.K.; Dr. David Davenport for the referral of patient CB; and Mary E. Wilson, Jack T. Stapleton, William M. Nauseef, and Robert A. Clark for suggestions and guidance and for reviewing the manuscript.

This work was supported by grants from the National Institutes of Health (NIH) (DK-01295, AI-28412, AI-20866) and the Department of Veterans' Affairs. Dr. Volpp is a Physician Scientist Award recipient from the NIH, an RJR/Nabisco Scholar in Immunology, and a Research Associate Career Award recipient from the Department of Veterans' Affairs.

\section{References}

1. Klebanoff, S. J. 1980. Oxygen metabolism and the toxic properties of phagocytes. Ann. Intern. Med. 93:480-489.

2. Babior, B. M. 1978. Oxygen-dependent microbial killing by phagocytes. $N$. Engl. J. Med. 298:659-725.

3. Clark, R. A. 1990 . The human neutrophil respiratory burst oxidase. $J$. Infect. Dis. 161:1140-1147.

4. Meier, B., A. R. Cross, J. T. Hancock, F. J. Kaup, and O. T. G. Jones. 1991. Identification of a superoxide-generating NADPH oxidase system in human fibroblasts. Biochem. J. 275:241-245.

5. Maly, F. E., A. R. Cross, O. T. G. Jones, G. Wolf-Vorbeck, C. Walker, C. A. Dahinden, and A. L. de Weck. 1988. The superoxide generating system of B cell lines: structural homology with the phagocytic oxidase and triggering via surface Ig. J. Immunol. 140:2334-2339.

6. Pick, E., and R. Gadba. 1988. Certain lymphoid cells contain the membrane-associated component of the phagocyte-specific NADPH oxidase. J. Immunol. 140:1611-1617.

7. Radeke, H. H., A. R. Cross, J. T. Hancock, O. T. G. Jones, M. Nakamura, V. Kaever, and K. Resch. 1991. Functional expression of NADPH oxidase components ( $\alpha$ - and $\beta$-subunits of cytochrome $b_{558}$ and $45-\mathrm{kDa}$ flavoprotein) by intrinsic human glomerular mesangial cells. J. Biol. Chem. 266:21025-21029.

8. Pick, E., T. Kroizman, and A. Abo. 1989. Activation of the superoxideforming NADPH oxidase of macrophages requires two cytosolic components: one of them is also present in certain nonphagocytic cells. J. Immunol. 143:41804187.

9. Maly, F. E., M. Nakamura, J. F. Gauchat, A. Urwyler, C. Walker, C. A. Dahinden, A. R. Cross, O. T. G. Jones, and A. L. de Weck. 1989. Superoxide-dependent nitroblue tetrazolium reduction and expression of cytochrome b-245 components by human tonsillar B lymphocytes and B cell lines. J. Immunol. 142:1260-1267.

10. Hancock, J. T., L. M. Henderson, and O. T. G. Jones. 1990. Superoxide generation by EBV-transformed B lymphocytes. Activation by IL- $1 \beta$, TNF- $\alpha$ and receptor independent stimuli. Immunology. 71:213-217.

11. Leca, G., G. Benichou, A. Bensussan, F. Mitenne, P. Galanaud, and A. Vazquez. 1991. Respiratory burst in human B lymphocytes: triggering of surface Ig receptors induces modulation of chemiluminescence signal. J. Immunol. 146:3542-3549.

12. Orkin, S. H. 1989. Molecular genetics of chronic granulomatous disease. Annu. Rev. Immunol. 7:277-307.

13. Clark, R. A., B. D. Volpp, K. G. Leidal, and W. M. Nauseef. 1990. Two cytosolic components of the human neutrophil respiratory burst oxidase translocate to the plasma membrane during cell activation. J. Clin. Invest. 85:714-721.

14. Clark, R. A., H. L. Malech, J. I. Gallin, H. Nunoi, B. D. Volpp, D. W. Pearson, W. M. Nauseef, and J. T. Curnutte. 1989. Genetic variants of chronic granulomatous disease: prevalence of deficiencies of two cytosolic components of the NADPH oxidase system. N. Engl. J. Med. 321:647-652.

15. Babior, B. M. 1991. The respiratory burst oxidase and the molecular basis of chronic granulomatous disease. Am. J. Hematol. 37:263-266.

16. Royer-Pokora, B., L. M. Kunkel, A. P. Monaco, S. C. Goff, P. E. Newburger, R. L. Baehner, F. S. Cole, J. T. Curnutte, and S. H. Orkin. 1986. Cloning the gene for an inherited disorder-chronic granulomatous disease-on the basis of its chromosomal location. Nature (Lond.). 322:32-38.

17. Dinauer, M. C., J. T. Curnutte, H. Rosen, and S. H. Orkin. 1989. A missense mutation in the neutrophil cytochrome $b$ heavy chain in cytochromepositive x-linked chronic granulomatous disease. J. Clin. Invest. 84:2012-2016.

18. Bolscher, B. G. J. M., M. de Boer, A. de Klein, R. S. Weening, and D. Roos. 1991. Point mutations in the B-subunit of cytochrome $b_{558}$ leading to X-linked chronic granulomatous disease. Blood. 77:2482-2487.

19. Dinauer, M. C., E. A. Pierce, G. A. P. Bruns, J. T. Curnutte, and S. H. Orkin. 1990. Human neutrophil cytochrome $b$ light chain (p22-phox). Gene structure, chromosomal location, and mutations in cytochrome-negative autosomal recessive chronic granulomatous disease. J. Clin. Invest. 86:1729-1737.

20. Casimir, C. M., H. N. Bu-Ghanim, A. R. F. Rodaway, D. L. Bentley, P. Rowe, and A. W. Segal. 1991. Autosomal recessive chronic granulomatous disease caused by deletion at a dinucleotide repeat. Proc. Natl. Acad. Sci. USA. 88:2753-2757.

21. Cohen-Tanugi, L., F. Morel, M.-C. Pilloud-Dagher, J. M. Seigneurin, P. Francois, M. Bost, and P. V. Vignais. 1991. Activation of $\mathrm{O}_{2}^{-}$-generating oxidase in an heterologous cell-free system derived from Epstein-Barr virus-transformed human B lymphocytes and bovine neutrophils-Application to the study of defects in cytosolic factors in chronic granulomatous disease. Eur. J. Biochem. 202:649-655.

22. Current Protocols in Immunology. 1991. J. E. Coligan, A. M. Kruisbeek, D. H. Margulies, E. M. Shevach, and W. Strober, editors. Greene Publishing Associates and Wiley-Interscience, New York.

23. Clark, R. A., and S. J. Klebanoff. 1978. Chronic granulomatous disease: studies of a family with impaired neutrophil chemotactic, metabolic and bactericidal function. Am. J. Med. 65:941-948.

24. Ochs, H. D., and R. P. Igo. 1973. The NBT slide test: a simple screening method for detecting chronic granulomatous disease and female carriers. $J$. Pediatr. 83:77-82.

25. Metcalf, J. A., J. I. Gallin, W. M. Nauseef, and R. K. Root. 1986. Laboratory Manual of Neutrophil Function. Raven Press, New York. 109 pp.

26. Clark, R. A., K. G. Leidal, D. W. Pearson, and W. M. Nauseef. 1987. NADPH oxidase of human neutrophils: subcellular localization and characterization of an arachidonate-activatable superoxide-generating system. J. Biol. Chem. 262:4065-4074.

27. Volpp, B. D., W. M. Nauseef, and R. A. Clark. 1988. Two cytosolic neutrophil oxidase components absent in autosomal chronic granulomatous disease. Science (Wash. DC). 242:1295-1297.

28. Volpp, B. D., W. M. Nauseef, J. E. Donelson, D. R. Moser, and R. A. Clark. 1989. Cloning of the cDNA and functional expression of the 47-kilodalton cytosolic component of human neutrophil respiratory burst oxidase. Proc. Natl. Acad. Sci. USA. 86:7195-7199.

29. Feinberg, A. P., and B. Vogelstein. 1984. A technique for radiolabeling DNA restriction endonuclease fragments to high specific activity. Anal. Biochem. 137:266-267.

30. Kawasaki, E. S. 1990. Amplification of RNA. In PCR protocols: A Guide to Methods and Applications. M. A. Innis, D. H. Gelfand, J. J. Sninsky, and T. J. White, editors. Academic Press, Inc., San Diego. 21-27.

31. Sanger, F., S. Nicklen, and A. R. Coulson. 1977. DNA sequencing with chain-terminating inhibitors. Proc. Natl. Acad. Sci. USA. 74:5463-5467.

32. Sugden, B., K. Marsh, and J. Yates. 1985. A vector that replicates as a plasmid and can be efficiently selected in B-lymphoblasts transformed by Epstein-Barr virus. Mol. Cell. Biol. 5:410-413.

33. Leto, T. L., K. J. Lomax, B. D. Volpp, H. Nunoi, J. M. G. Sechler, W. M. Nauseef, R. A. Clark, J. I. Gallin, and H. L. Malech. 1990. Cloning of a 67-kD 
neutrophil oxidase factor with similarity to a noncatalytic region of $\mathrm{p} 60_{\mathrm{c}-\mathrm{sc}}$. Science (Wash. DC). 248:727-730.

34. Hibbs, M. L., A. J. Wardlaw, S. A. Stacker, D. C. Anderson, A. Lee, T. M. Roberts, and T. A. Springer. 1991. Transfection of cells from patients with leukocyte adhesion deficiency with an integrin B subunit (CD18) restores lymphocyte function-associated antigen-1 expression and function. J. Clin. Invest. 85:674681.

35. Gutkind, J. S., D. C. Link, S. Katamine, P. Lacal, T. Miki, T. J. Ley, and K. C. Robbins. 1991. A novel c- $f$ gr exon utilized in Epstein-Barr virus-infected B lymphocytes but not in normal monocytes. Mol. Cell. Biol. 11:1500-1507.

36. Patel, M., L. Faulkner, D. R. Katz, and P. M. Brickell. 1991. The c- $f g r$ proto-oncogene: expression in Epstein-Barr virus-infected $\mathrm{B}$ lymphocytes and in cells of the myelomonocytic and granulocytic lineages. Pathobiology. 59:289292.

37. Leto, T. L., M. C. Garrett, H. Fujii, and H. Nunoi. 1991. Characterization of neutrophil NADPH oxidase factors p47-phox and p67-phox from recombinant baculoviruses. J. Biol. Chem. 266:19812-19818.

38. Curnutte, J. T., P. J. Scott, and L. A. Mayo. 1989. Cytosolic components of the respiratory burst oxidase: resolution of four components, two of which are missing in complementing types of chronic granulomatous disease. Proc. Natl. Acad. Sci. USA. 86:825-829.

39. Umei, T., B. M. Babior, J. T. Curnutte, and R. M. Smith. 1991. Identification of the NADPH-binding subunit of the respiratory burst oxidase. J. Biol. Chem. 266:6019-6022.

40. Quinn, M. T., C. A. Parkos, L. Walker, S. H. Orkin, M. C. Dinauer, and A. J. Jesaitis. 1989. Association of a ras-related protein with cytochrome $b$ of human neutrophils. Nature (Lond.). 342:198-200.
41. Eklund, E. A., M. Marshall, J. B. Gibbs, C. D. Crean, and T. G. Gabig. 1991. Resolution of a low molecular weight $G$ protein in neutrophil cytosol required for NADPH oxidase activation and reconstitution by recombinant Krev-1 protein. J. Biol. Chem. 266:13964-13970.

42. Abo, A., E. Pick, A. Hall, N. Totty, C. G. Teahan, and A. W. Segal. 1991. Activation of the NADPH oxidase involves the small GTP-binding protein p21 $1_{\mathrm{rac}}$. Nature (Lond.). 353:668-670.

43. Abo, A., and E. Pick. 1991. Purification and characterization of a third cytosolic component of the superoxide-generating NADPH oxidase of macrophages. J. Biol. Chem. 266:23577-23585.

44. Bokoch, G. M., L. A. Quilliam, B. P. Bohl, A. J. Jesaitis, and M. T. Quinn. 1991. Inhibition of raplA binding to cytochrome $b_{558}$ of NADPH oxidase by phosphorylation of raplA. Science (Wash. DC). 254:1794-1796.

45. Krawczak, M., and D. N. Cooper. 1991. Gene deletions causing human genetic disease: mechanisms of mutagenesis and the role of local DNA sequence environment. Hum. Genet. 86:425-441.

46. Gibbs, R. A., P.-N. Nguyen, A. Edwards, A. B. Citivello, and C. T. Caskey 1990. Multiplex DNA deletion detection and exon sequencing of the hypoxanthine phosphoribosyltransferase gene in Lesch-Nyhan families. Genomics. 7:235-244.

47. Kunkel, T. A. 1990. Misalignment-mediated DNA synthesis errors. Biochemistry. 29:8003-8011.

48. Bebenek, K., and T. A. Kunkel. 1990. Frameshift errors initiated by nucleotide misincorporation. Proc. Natl. Acad. Sci. USA. 87:4946-4950.

49. Weaver, D. T., and M. L. DePamphilis. 1982. Specific sequences in native DNA that arrest synthesis by DNA polymerase $\alpha$. J. Biol. Chem. 257:2075-2086. 